удк 332.146

\title{
ОРГАНІЗАЦІЙНО-ЕКОНОМІЧНІ АСПЕКТИ ЕФЕКТИВНОСТІ ОБГРУНТУВАННЯ КОНЦЕСІЙ У ДОРОЖНЬОМУ БУДІВНИЦТВІ
}

\section{ORGANIZATIONAL AND ECONOMIC ASPECTS OF JUSTIFICATION OF CONCESSIONS IN ROAD CONSTRUCTION}

\author{
Юрченко Анна Станіславівна \\ здобувач, \\ Національний транспортний університет \\ ORCID: https://orcid.org/0000-0003-2051-1986 \\ Yurchenko Anna \\ National Transport University
}

\begin{abstract}
Стаття присвячена актуальним питанням характеристики організаційних та економічних аспектів обґрунтування концесій у дорожньому будівництві. Проаналізовано та систематизовано фрактори що мають вплив на успішну реалізацію проєктів дорожнього будівництва на засадах концесії. Серед інших розкрито низку базових принципів, серед яких виділено: прозорість та відповідальність; конкурсність; передача ризику; забезпечення конкурентоспроможності послуг, виконання яких передається з державного сектору до приватного; інноваційний розвиток; зрозумілість та передбачуваність; безперервність надання послуг; рівність учасників концесії; стабільність та гнучкість умов контракту; врахування специфріки об'єкту проекту концесії; економічна та фрінансова стійкість; невтручання держави у господарську діяльність приватного партнера тощо. Досліджено світовий досвід застосування концесій як форми державно-приватного партнерства. Досліджено тенденції активності проєктів в Європейському союзі.
\end{abstract}

Ключові слова: концесія, державно-приватне партнерство, дорожнє будівництво, проєкти дорожнього будівництва.

Статья посвящена актуальным вопросам характеристики организационных и экономических аспектов обоснования концессий в дорожном строительстве. Проанализированы и систематизированы фракторы, что оказывают влияние на успешную реализацию проектов дорожного строительства на основе концессии. Среди других раскрыт ряд базовых принципов, среди которых выделены: прозрачность и ответственность; конкурсность; передача риска; обеспечение конкурентоспособности услуг, выполнение которых передается из государственного сектора в частный; инновационное развитие; понятность и предсказуемость; непрерывность оказания услуг; равенство участников концессии; стабильность и гибкость условий контракта; учет специфики объекта проекта концессии; экономическая и фринансовая устойчивость; невмешательство государства в хозяйственную деятельность частного партнера; тому подобное. Описан мировой опыт применения концессий как формы государственно-частного партнерства. Исследованы тенденции активности проектов в Европейском союзе.

Ключевые слова: концессия, государственно-частное партнерство, дорожное строительство, проекты дорожного строительства.

The article is devoted to topical issues of characterization of organizational and economic aspects of substantiation of concessions in road construction. The factors influencing the successful implementation of road construction projects on the basis of concession are analyzed and systematized. Among others, a number of basic principles are revealed, among which are: transparency and accountability; competitiveness; risk transfer; ensuring the competitiveness of services, the implementation of which is transferred from the public sector to the private sector; innovative development; clarity and predictability; continuity of service provision; equality of concession participants; stability and flexibility of contract terms; taking into account the specifics of the object of the concession project; economic and financial stability; non-interference of the state in the economic activity of a private partner; etc. The world experience of using concessions as a form of public-private partnership is studied. Trends in project activity in the European Union are studied. The main factors of concession success in road construction through methods 
and forms of state supervision over the partnership between the state and private investors are revealed. The state is characterized as a body that forms the institutional environment, creates legal and organizational preconditions for the process of establishing partnerships, formulates strategies and principles for establishing business partnerships with the government and society. To ensure the success of projects under the concession system, the legal aspects and preconditions created by the state for the implementation of these projects are highlighted. The main stages of the project life cycle, which must be taken into account to ensure the effective and successful implementation of projects on the basis of concessions in road construction, are revealed and characterized. The preconditions for the success of public-private partnership in the development of transport infrastructure and projects based on concessions in particular are highlighted. The main aspects and criteria for assessing the state's readiness to implement road construction projects on the basis of concessions are revealed, among which is the presence of political support for partnership between the state and business by the government; the government's ability to manage concessions; the government's ability to manage the PPP process (completion); organization of implementation (realization) of projects.

Keywords: concession, public-private partnership, road construction, road construction projects.

Постановка проблеми. Розвинена мережа автомобільних доріг є запорукою стабільного й динамічного зростання економіки не тільки окремих регіонів, а й держави у цілому, підвищення рівня життя населення, базовим чинником національної безпеки та успішної інтеграції у світовий економічний простір.

Проекти, пов'язані 3 розвитком об'єктів транспортної інфрраструктури, як правило, потребують акумуляції значних обсягів фрінансових ресурсів. В умовах звичайних бюджетних обмежень, а часто й значного дефріциту бюджету часто вони часто залишаються нереалізованими. Це зумовлює необхідність пошуку інших джерел інвестиційних ресурсів, що можуть бути залучені у дорожнє будівництво, зокрема приватних. Найбільш поширеною у світі фрормою залучення приватних інвестицій в дорожнє будівництво є концесії.

Аналіз останніх досліджень і публікацій. Питанню використання концесії у дорожньому будівництві приділяли увагу: О.І. Білик, Ю.О. Блинда, Н.М. Крохмальна [1] в частині управління соціальними ризиками в умовах розвитку дорожньої концесії, Дмітрієва О. [2] в частині еволюції інституту концесії в транспортній інсрраструктурі, В. Григоренко, М. Малихін, Г. Петренко [3] в частині підсистеми аналітичного супроводу інституційних учасників при реалізації проєктів ДПП у будівництві, Shu H., Durango-Cohen P.L. [4] в частині характеристики оптимальних аукціонів для концесій на дороги, Безуглий А.О. [5] в частині підходів до підвищення якості автомобільних доріг на основі довгострокового планування, тощо.

Виділення невирішених раніше частин загальної проблеми. Але частина питань, що характеризують саме організаційноекономічні аспекти ефективності обґрунтування концесій у дорожньому будівництві залишаються не розкритими, а проблеми не вирішеними.
Формулювання цілей статті (постановка завдання). Метою статті $€$ характеристика організаційних та економічних аспектів ефективності обґрунтування концесій у дорожньому будівництві.

Виклад основного матеріалу дослідження. Враховуючи об'єктивно обмежені бюджетні ресурси, наявні для реалізації суспільно значущих проектів, спрямованих на створення суспільних благ (включаючи транспортну інфрраструктуру), уряди все більшого числа країн звертаються до приватних інвесторів для спільної реалізації таких проектів. Механізм спільної взаємодії між державою та приватними інвесторами отримав назву державно-приватного партнерства (ДПП).

Різні форми ДПП активно використовуються в різних сорерах транспортної інфрраструктури, включаючи будівництво, експлуатацію та обслуговування автомобільних доріг, мостів, тунелів, аеропортів, портів, залізниць та ліній розгалуження метро, впровадження систем контролю руху та розвиток міського наземного транспорту. Реалізуючи проекти на основі ДПП, уряди залучають інвестиції приватного сектору як для нового будівництва, так і для розвитку існуючої транспортної інораструктури.

Концесії є найбільш розвиненою, прогресивною та складною формою партнерства держави та приватного бізнесу на сучасному етапі:

- на відміну від контрактних відносин, вони мають багатоцільовий та довгостроковий характер, що дає можливість обом сторонам здійснювати стратегічне прогнозування та планування своєї діяльності;

- за договорами концесії ризики проектів перерозподіляються між усіма його учасниками: державою, концесіонером, інвесторами, фрінансовими інститутами, страховими компаніями тощо, завдяки чому суттєво підвищується життєспроможність таких проектів. 
Таблиця 1

Зміни європейського ринку ДПП у 2016-2019 роках

\begin{tabular}{|c|c|c|c|c|}
\hline Показник & 2016 & 2017 & 2018 & 2019 \\
\hline $\begin{array}{l}\text { Кількість проєктів, } \\
\text { що досягли фрінансового } \\
\text { закриття }\end{array}$ & 69 & 42 & 39 & 29 \\
\hline $\begin{array}{l}\text { Загальний обсяг інвестицій } \\
\text { у проєкти, що досягли } \\
\text { рівня фрінансового } \\
\text { закриття, млрд Євро }\end{array}$ & 11,8 & 14,4 & 14,6 & 9,8 \\
\hline $\begin{array}{l}\text { 3міна обсягу інвестованого } \\
\text { капіталу до попереднього } \\
\text { року: У млрд грн }\end{array}$ & $-3,6$ & $+2,4$ & +30 & $-4,8$ \\
\hline y \% & -22 & +20 & $+8,6$ & -31 \\
\hline $\begin{array}{l}\text { Зміна кількості проєктів } \\
\text { до попереднього року }\end{array}$ & +20 & -27 & -3 & -10 \\
\hline y \% & +41 & -39 & $-7,1$ & -25 \\
\hline $\begin{array}{l}\text { Найбільш активна } \\
\text { країна за здійсненими } \\
\text { інвестиціями }\end{array}$ & Великобританія & Туреччина & Туреччина & Великобританія \\
\hline $\begin{array}{l}\text { Найбільш активна країна } \\
\text { за кількістю проєктів }\end{array}$ & Великобританія & Великобританія & Франція & Франція \\
\hline $\begin{array}{l}\text { Найбільш активний сектор } \\
\text { економіки за обсягами } \\
\text { інвестицій }\end{array}$ & Трансп. інфрр. & Трансп. інфрр. & Трансп. інфрр. & Трансп. інфрр. \\
\hline $\begin{array}{l}\text { Найбільш активний сектор } \\
\text { економіки за кількістю } \\
\text { проєктів }\end{array}$ & Освіта & $\begin{array}{l}\text { Трансп. інфрр. } \\
\text { Освіта }\end{array}$ & Освіта & Трансп. інсрр. \\
\hline
\end{tabular}

Джерело: розроблено автором за [6]

Незважаючи те, що кількість проєктів ДПП у Європі скорочується, зміна обсягу інвестованого капіталу до попереднього року залишається високою, а проєкти в транспортну інфрраструктуру займають перше місце (таблиця 1).

Реалізація проєктів дорожнього будівництва на засадах концесії передбачає кооперацію ресурсів та зусиль державного та приватного партнера. Така кооперація має організаційне оформлення, передбачає обов'язковість договірних відносин 3 розподілом зобов'язань щодо ресурсного, фрінансового інформаційного забезпечення, розподілом доходу, отриманого в результаті експлуатації об'єкта концесії та ризиків, що виникають у сорері фрінансування, проєктування, будівництва, експлуатації об'єкта дорожнього будівництва.

Успішність застосування концесій у дорожньому будівництві залежить від дотримання низки базових принципів: прозорість та відповідальність; конкурсність; передача ризику; забезпечення конкурентоспроможності послуг, виконання яких передається 3 державного сектору до приватного; інноваційний розвиток; зрозумілість та передбачуваність; безперервність надання послуг; рівність учасників концесії; стабільність та гнучкість умов контракту; врахування специфріки об'єкту проекту концесії; економічна та фрінансова стійкість; невтручання держави у господарську діяльність приватного партнера; можливість залучення третіх осіб (підрядників, інвесторів тощо) до реалізації проекту концесії; гарантії та інші види державної підтримки концесії; компенсація; справедливість; оптимальне державне (публічне) управління; захист державою інтересів споживачів послуг; забезпечення співвідношення ціни та якості; розширення прав і можливостей соціальних груп.

Зокрема, за матеріалами Світового банку, найбільш вдалі проекти з дорожнього будівництва у 1990-2019 роках наведено в таблиці 2.

Одним 3 основних фракторів успіху концесії у дорожньому будівництві $€$ методи та форми державного нагляду за партнерством між державою та приватними інвесторами. Держава формує інституційне середовище, створює правові та організаційні передумови для процесу встановлення партнерських відносин, формулює стратегії та принципи налагодження ділових партнерств 3 урядом та 
Інвестиції у проекти дорожнього будівництва у 1990-2019 роках, що є вдалими (за даними Світового банку), млн доларів США

\begin{tabular}{|c|c|c|c|c|c|}
\hline Perion & 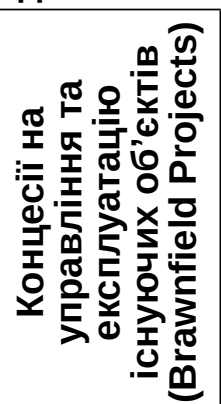 & 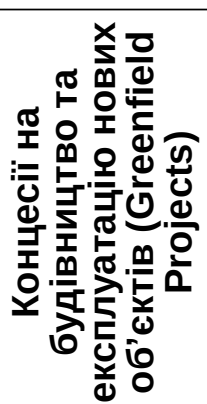 & 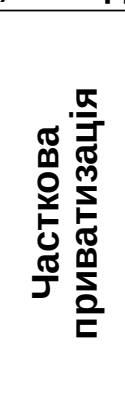 & 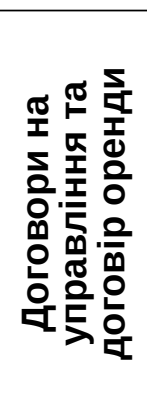 & 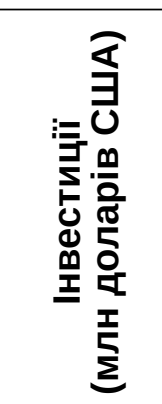 \\
\hline Східна Азія і Тихий океан & 9732 & 40654 & 3417 & 0 & 53804 \\
\hline Європа та Центральна Азія & 5637 & 20307 & 0 & 0 & 25944 \\
\hline $\begin{array}{l}\text { Латинська Америка } \\
\text { та Карибський басейн }\end{array}$ & 94044 & 23364 & 0 & 427 & 117834 \\
\hline Південна Азія & 70536 & 8965 & 0 & 0 & 79501 \\
\hline Афррика на південь від Сахари & 1981 & 1076 & 0 & 0 & 3057 \\
\hline Разом & 181930 & 94366 & 3417 & 427 & 280140 \\
\hline Разом у відсотках & 64,94 & 33,69 & 1,22 & 0,15 & 100 \\
\hline
\end{tabular}

суспільством. Країна також є одним із партнерів. Вона отримує концесійні платежі від компаній, які реалізують проект, контролює ціни (тарифи), дохід, якість послуг та дотримання умов, передбачених у відповідних договорах та контрактах. Водночас, для підтримки незаможних верств населення, при фрормуванні тарифної політики держава визначає необхідність надання субсидій та дотацій приватному бізнесу, гарантій - інвесторам та кредиторам при вирішенні проблем з фрінансуванням.

Для підтримки успішної реалізації концесій у дорожньому будівництві держава може надавати спеціальним проектним компаніям податкові канікули або податкові пільги для проектів. ЄЕК ООН звернула увагу на провідну роль держави у забезпеченні успішної реалізації таких проєктів. Держава несе відповідальність за фрормування прозорого та ефективного національного законодавства для розвитку концесій як форми ДПП.

Правове регулювання у сфрері концесій, як фрорми ДПП, може бути загальним, охоплювати всі сектори та сектори економіки, або галузевим. Також повинні бути чіткими фрункції та повноваження урядів усіх рівнів та відповідальність за виконання зобов'язань, взятих на себе державою.

Правові, інституційні та організаційні передумови, створені державою для реалізації проектів на засадах концесій, полягають у створенні необхідного операційного каркасу для прийнятного для держави рівня ризику відповідальності та умов і ризиків діяльності для приватного бізнесу.

Необхідною передумовою мотивації приватного бізнесу до участі у проєктах дорожнього будівництва на умовах концесії $€$ наявність чітких правових меж. Вони забезпечують зниженню політичних ризиків та надають приватному бізнесу конкурентну перевагу у вигляді отриманих державних гарантій.

Важливою передумовою успішності концесій у ссрері дорожнього будівництва $\epsilon$ ретельна підготовка відповідних проектів. На цій стадії життєвого циклу проекту необхідно враховувати наступні аспекти:

- забезпечення конкурсного прозорого відбору приватного партнера;

- необхідність адаптації концесії до конкретних територіальних і часових умов реалізації проекту дорожнього будівництва;

- участь суспільства у прийнятті рішень щодо доцільності реалізації проекту на засадах концесії та подальшому контролі за досягненням поставлених перед концесіонером завданнями: забезпечення кращого співвідношення ціни та якості послуг, їх доступності споживачам (з урахуванням рівня їхньої платоспроможності), покращення екологічної ситуації регіону тощо;

- забезпечення взаємодоповнюваності та сумісності цілей державного та приватного партнерів;

- створення та використання конкретних інструментів, спрямованих на полегшення 
підготовки проектів концесії. Зокрема, методичного інструментарію щодо обґрунтування доцільності концесій.

Також необхідною передумовою успішності концесій у дорожньому будівництві $\epsilon$ їхня есрективна реалізація. Вона залежить від:

- ретельного структурування концесійних договорів. Вони повинні містити конкретні характеристики проекту, зобов'язання та способи вирішення можливих конфрліктів інтересів його учасників. Вони також повинні бути гнучкими, інноваційними та прибутковими;

- наявності досвіду співпраці держави і приватного бізнесу щодо реалізації проєктів дорожнього будівництва на умовах концесії;

- рівень довіри між партнерами. Контракт повинен передбачати, що партнери поділяють ризики та відповідальність один перед другим щодо виконання умов контракту та досягнення цільових результатів проекту;

- ефрективного виконання державою керівних фрункцій у ссрері концесій, зокрема у дорожньому будівництві. Дана передумова набуває важливості, враховуючи стратегічне значення мережі автомобільних доріг як для національної безпеки, розвитку зовнішньоекономічних зв'язків, так й забезпечення сталого розвитку національної економіки та підвищення рівня життя населення;

- використання державних фрінансових ресурсів для мобілізації більш значних приватних інвестицій у реалізацію концесійних проєктів у дорожньому будівництві.

Узагальнюючи результати досліджень, проведених фрінансово-кредитними інституціями, науковцями та практиками серед важливих фракторів успіху реалізації проектів будівництва та експлуатації автомобільних доріг на умовах концесії слід відзначити необхідність:

- розвиненого інституційного середовища;

- політичної підтримки реалізації концесій у дорожньому будівництві;

- чіткості, стабільності та прозорості концесійного законодавства;

- якості та ретельності підготовки проектів ДПП;

- технічної можливості реалізації проекту ДПП;

- прозорості та есрективності тендерних процедур;

- обґрунтованого розподілу ризиків, доходів та витрат між державним та приватним партнером;

- надання державної підтримки концесіонерам та державних гарантій кредиторам й інвесторам;
- срормування оптимальної структури капіталу концесійної компанії;

- доступності ресурсів фрінансового ринку;

- найкращого співвідношення ціни та якості в результаті концесії;

- сприятливого економічного середовища;

- наявності консультаційної, методичної та організаційної підтримки реалізації концесійного проекту;

- суспільної підтримки реалізації концесій у дорожньому будівництві.

Вирішальною передумовою успішності ДПП у розвитку транспортної інфрраструктури $\epsilon$ готовність держави сприйняти бізнес як рівного партнера.

Основні аспекти та критерії оцінювання готовності держави до реалізації проектів дорожнього будівництва на засадах концесії:

- Наявність політичної підтримки партнерських взаємодій держави і бізнесу з боку уряду;

- Здатність уряду до управління концесіями;

- Здатність уряду до управління процесом ДПП (закінчення);

- Організація виконання (реалізації) проектів.

Вивчення світового досвіду використання концесій у дорожньому будівництві дало можливість визначити фрактори, що перешкоджають активному залученню приватних інвестицій, зокрема це: низький ступінь довіри з боку іноземних інвесторів; слабкий національний ринок капіталу; повільне зростання доходів в країні; низький рівень правового захисту інтересів приватного бізнесу; традиційні методи управління державними установами; низька платоспроможність користувачів автомобільних доріг, наявність та розвиненість альтернативних автомобільних доріг тощо.

Висновки. Через недостатнє фрінансування державного сектору економіки, виникають можливості для партнерства приватного сектору у будівництві доріг. Приватний сектор міг би брати участь у різних проєктах розбудови доріг та дорожньої інфрраструктури за умовами концесії, включаючи будівництво та обслуговування доріг, технічне обслуговування та забезпечення безпеки транспортних засобів та безпеки населення тощо. Основні виклики можуть включати питання законодавства, неясності у співпраці, політичну та організаційну нестійкість, фрінансові труднощі уряду та відсутність досвідчених експертів у сорері ДПП та концесії зокрема. Однак, є значні переваги, включаючи високу ефективність у впровадженні програм, що охоплює слабкі сторони державного сектору, ефективне та результативне управління застосуванням 
ДПП. Організаційно-економічні аспекти забезпечення ефрективної реалізації договорів концесії включають визначення пріоритетів діяльності, квалісрікації приватного сектора, розробки політики та правових основ ДПП, створення спільної мови між державними та приватними сторонами, намаганням виправдати очікування приватного сектора 3 боку державного сектору, розробку всеосяжного та надійного контракту та виховання суспільної культури прийняття приватного сектору у сорері будівництва доріг.

\section{СПИСОК ВИКОРИСТАНИХ ДЖЕРЕЛ:}

1. Білик О. І., Блинда Ю. О., Крохмальна Н. М. Особливості управління соціальними ризиками в умовах розвитку дорожньої концесії. Вісник Національного університету «Львівська політехніка». Серія : Проблеми економіки та управління. 2020. № 2(6). С. 115-124.

2. Дмітрієва О. Еволюція інституту концесії як основи розвитку транспортної інфраструктури. Економіка транспортного комплексу. 2020. № 36. С. 23-23.

3. Григоренко В., Малихін М., Петренко Г. Прикладні підсистеми аналітичного супроводу інституційних учасників при реалізації проєктів ДПП у будівництві. Управління розвитком складних систем. 2021. № 45. C. 141-149.

4. Shu H., Durango-Cohen P. L. (2021) On the design of optimal auctions for road concessions: Firm selection, government payments, toll and capacity schedules with imperfect information // Transportation Research Part B: Methodological. T. 146. P. 210-236.

5. Безуглий А.О. Системный подход к качеству автодорог на основе долгосрочного планирования. Будівельний журнал. 2017. № 6(130). С. 72-73.

6. World Bank Group. Open knowledge repository. Public-Private Partnership in the road sector. URL: https://openknowledge.worldbank.org/discover?query=public-private\%20partnership

\section{REFERENCES:}

1. Bilyk O.I., Blynda Yu.O., Krokhmalna N.M. (2020) Osoblyvosti upravlinnya sotsialnymy ryzykamy v umovakh rozvytku dorozhnoyi kontsesiyi [Features of social risk management in the development of road concessions]. Visnyk Natsionalnoho universytetu "Lvivska politekhnika". Seriya: Problemy ekonomiky ta upravlinnya, no. 2(6), pp. 115-124. (in Ukrainian)

Dmitriyeva O. (2020) Evolyutsiya instytutu kontsesiyi yak osnovy rozvytku transportnoyi infrastruktury [The evolution of the institution of concession as a basis for the development of transport infrastructure]. Ekonomika transportnoho kompleksu, no. 36, pp. 23-23. (in Ukrainian)

2. Hryhorenko V., Malykhin M., Petrenko H. (2021) Prykladni pidsystemy analitychnoho suprovodu instytutsiynykh uchasnykiv pry realizatsiyi proyektiv DPP u budivnytstvi [Applied subsystems of analytical support of institutional participants in the implementation of PPP projects in construction]. Upravlinnya rozvytkom skladnykh system, no. 45, pp. 141-149. (in Ukrainian)

3. Shu H., Durango-Cohen P.L. (2021) On the design of optimal auctions for road concessions: Firm selection, government payments, toll and capacity schedules with imperfect information // Transportation Research Part B: Methodological, t. 146, pp. 210-236.

4. Bezugliy A.O. (2017) Sistemnyy podkhod k kachestvu avtodorog na osnove dolgosrochnogo planirovaniya [A systematic approach to the quality of roads based on long-term planning]. Budívelniy zhurnal, no. 6(130), pp. 72-73. (in Ukrainian) 